\title{
Hemoglobin catalyzes ATP-synthesis in human erythrocytes: A murburn model
}

\author{
Abhinav Parashar*, Vivian David Jacob, Daniel Andrew Gideon, Kelath Murali Manoj* \\ *Corresponding authors, Satyamjayatu: The Science \& Ethics Foundation, \\ Snehatheeram, Kulappully, Shoranur-2, Kerala, India-679122. \\ murman@satyamjayatu.com
}

\begin{abstract}
Blood hemoglobin $(\mathrm{Hb})$ is the most abundant globular protein in humans, known to transport oxygen. Erythrocytes have $\sim 10^{-3} \mathrm{M}$ concentration levels of ATP in steady-state and we estimate that this high cannot be formed from $10^{-4}-10^{-7} \mathrm{M}$ levels of precursors via substratelevel phosphorylation of glycolysis. To account for this discrepancy, we propose that Hb serves as a 'murzyme' (a redox enzyme working along the principles of murburn concept), catalyzing the synthesis of the major amounts of ATP found in erythrocytes. This proposal is along the lines of our earlier works demonstrating DROS (diffusible reactive oxygen species) mediated ATPsynthesis as a thermodynamically and kinetically viable mechanism for physiological oxidative phosphorylation. We support the new hypothesis for $\mathrm{Hb}$ with theoretical arguments, experimental findings of reputed peers and in silico explorations. Using in silico methods, we demonstrate that adenoside nucleotide and 2,3-bisphosphoglycerate (2,3-BPG) binding sites are located suitably on the monomer/tetramer, thereby availing facile access to the superoxide emanating from the heme center. Our proposal explains earlier reported in situ experimental findings/suggestions of 2,3-BPG and ADP binding at the same locus on $\mathrm{Hb}$. The binding energy is in the order of 2,3-BPG > NADH > ATP > ADP > AMP and agrees with earlier reports, potentially explaining the bioenergetic physiology of erythrocytes. Also, the newly discovered site for 2,3-BPG shows lower affinity in fetal $\mathrm{Hb}$ (as compared to adults) explaining oxygen transfer from mother to embryo. The findings pose significant implications in routine physiology and pathologies like sickle cell anemia and thalassemia.
\end{abstract}

Keywords: murburn concept; murzyme; hemoglobin; ATP, erythrocytes; RBC; glycolysis; oxygen-binding; reactive oxygen species 


\section{Introduction: Energetics of erythrocytes}

We have demonstrated the murburn model of redox enzyme function in xenobiotic metabolism (Manoj et al., 2016a; Parashar and Manoj, 2021), aerobic respiration (Manoj et al., 2019a; Manoj et al., 2020; Manoj et al., 2019b) and oxygenic photosynthesis (Gideon et al., 2020; Manoj and Manekkathodi, 2021). We had introduced the term 'murzyme' five years ago, to connote those redox enzymes that work along the murburn concept (Manoj et al., 2016b; Venkatachalam et al., 2016). Murburn concept summarizes a 'mured burning' (closed oxidative process in cells/organelles) or ' $m$ ild $u$ nrestricted redox catalysis' occurring via interactive equilibriums among component $\boldsymbol{m}$ olecules, $\boldsymbol{u}$ nbound ions and radicals. Herein, we propose that hemoglobin, the predominant oxygen-transporting protein of red blood corpuscles (RBC or erythrocytes), also serves as a murzyme that synthesizes ATP using diffusible reactive (oxygen) species or DR(O)S.

The source of energy for human erythrocytes is glucose $(\sim 5 \mathrm{mM})$ availed from blood fluid (plasma). RBCs depend on glycolysis for the utilization of glucose, as shown in Figure 1. Until the final $\left(10^{\text {th }}\right)$ step of glycolysis, the 2 ATP molecules that are consumed (at the 6 carbon 'investment' stage) and 2 ATP molecules are produced from two molecules of 1,3bisphosphoglycerate (1,3-BPG, in the $7^{\text {th }}$ step of the 3 carbon 'payoff' stage). ATP cannot be generated from NADH (produced in the $6^{\text {th }}$ step of glycolysis) by "ETC-proton pumpschemiosmosis-Complex V" mechanism of oxidative phosphorylation, as human RBCs lack mitochondria. Therefore, the net ATP productivity of glycolysis depends on the last $\left(10^{\text {th }}\right)$ step catalyzed by pyruvate kinase, which is the substrate level phosphorylation of ADP from phosphoenolpyruvate (PEP), to give pyruvate (Pyr) and ATP. The mass-charge balanced reaction catalyzed by the enzyme is represented by (Garrett and Grisham, 1999):

$$
\begin{gathered}
\text { Phosphoenolpyruvate }{ }^{3-}+\mathrm{ADP}^{3-}+\mathrm{H}^{+} \rightarrow \text { Pyruvate }^{-}+\mathrm{ATP}^{4-} \\
K_{\mathrm{eq}}=([\mathrm{Pyr}][\mathrm{ATP}]) /\left([\mathrm{PEP}][\mathrm{ADP}]\left[\mathrm{H}^{+}\right]\right)
\end{gathered}
$$

The equilibrium driven synthesis by pyruvate kinase would give $[\mathrm{ATP}]=\mathrm{K}_{\mathrm{eq}} \mathrm{x}[\mathrm{PEP}] \mathrm{x}[\mathrm{ADP}] \mathrm{x}$ $\left[\mathrm{H}^{+}\right] /[\mathrm{Pyr}]$. Transposing the equation and substituting the values of $K_{\text {eq }}$ (from $\Delta_{\mathrm{r}} G^{\circ} \sim-31$ $\mathrm{kJ} / \mathrm{mol}$ ), physiological concentrations of the reactants and metabolites (Berg et al., 2002; Garrett and Grisham, 1999), we get the concentration of [ATP]:

$=\sim 10^{5} \times\left[2.3 \times 10^{-5}\right] \times\left[1.4 \times 10^{-4}\right] \times\left[\sim 10^{-7}\right] /\left[5.1 \times 10^{-5}\right]$ 


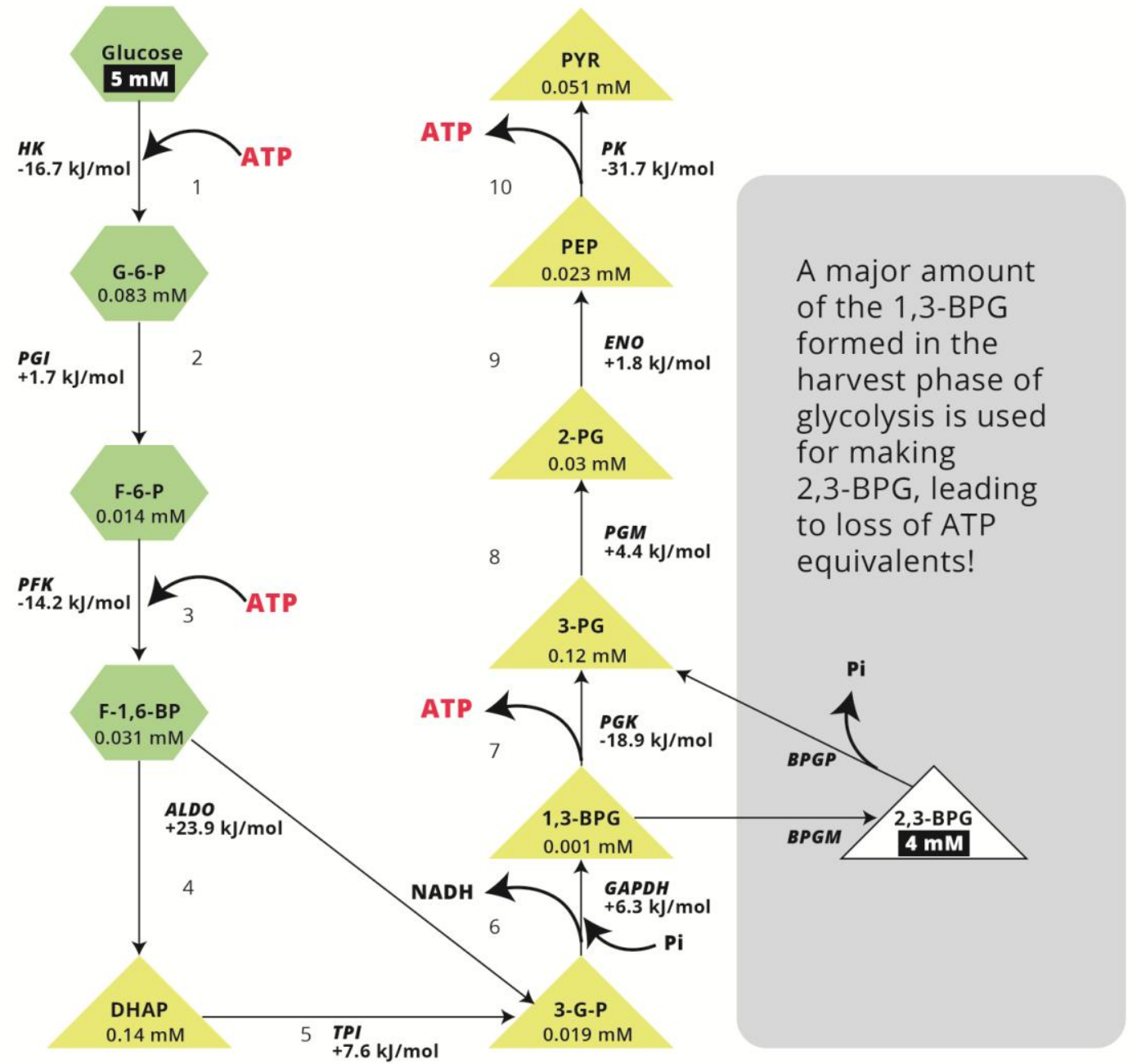

Figure 1: The glycolytic production of ATP in erythrocytes is not an energetically efficient process.

The calculation above gives equilibrium driven ATP formation at only $\sim 0.63 \mu \mathrm{M}$, which is 5500 folds lower than the experimental concentrations of $\sim 3.5 \mathrm{mM}$ ATP found in RBC (Xu et al., 2019). It is to be noted that except for the ATP-involving steps (two each at the six-carbon and three-carbon stages), all reactions are characterized by a positive Gibbs free energy term (Garrett and Grisham, 1999). Therefore, the viability of glycolysis critically depends on ATP/ADP ratio. The $7^{\text {th }}$ step of glycolysis mediated by phosphoglycerate kinase (1,3-bisphosphoglycerate $\rightarrow 3$ phosphoglycerate) is regulatory, and is favorable when [ADP] $>$ [ATP]. However, the physiological concentration of ADP is only $\sim 0.14 \mathrm{mM}$ in RBC (Berg et al., 2002; Garrett and Grisham, 1999), which is $\sim 1 / 15$ to $1 / 25$ of ATP concentration. Also, the concentration of 1,3BPG in erythrocytes is usually very low $(\sim 1 \mu \mathrm{M})$ because most of this metabolite is converted to 
2,3-BPG (which is maintained at $\sim 4$ to $6 \mathrm{mM}$ ) by the enzyme bisphosphoglycerate mutase. Recycling of 2,3-BPG into the glycolytic intermediate of 3-phosphoglycerate is mediated via a phosphatase enzyme (giving Pi and protons). Therefore, the amount of ATP produced in the $7^{\text {th }}$ step would only be a fraction of the ATP consumed in the investment step. This implies that even the tenth step would be needed to make up for the energy deficit, if glycolysis were the only pathway for ATP-synthesis. Further, anaerobic production of lactate from pyruvate is needed/viable for redox cycling in myocytes and other cells that are conditionally deprived of oxygen supply. This non-spontaneous reaction with $\Delta_{\mathrm{r}} G^{\circ} \sim 25 \mathrm{~kJ} / \mathrm{mol}$ (Cox and Nelson, 2008) cannot be a part of the routine metabolic cycle of RBC, which has a highly oxic environment. Also, it does not make sense to have a pathway make NADH and then degrade it for futile reasons (as NADH is needed in ample amounts to keep the large number of $\mathrm{Hb}$ molecules reduced within the RBCs). Even if we disregard steady-state or equilibrium considerations, reaction stoichiometry (from the highlighted equation) would afford maximally $\sim 140 \mu \mathrm{M}$ ATP (equivalent to the $\sim 140 \mu \mathrm{M}$ ADP found in $\mathrm{RBC}$ ) or minimally $\sim 50 \mathrm{nM}$ (equivalent to proton concentration) or moderately $23 \mu \mathrm{M}$ (equivalent to phosphoenolpyruvate concentration). These values are several folds or orders lower than the physiological concentrations of ATP in RBC. (Each step of the serial scheme of glycolysis would be dependent on the experimental orderterms of all reaction components; and each step's rate constants would be required to calculate the accurate amounts of ATP generated in the tenth step. However, a rough approximation is possible with the stoichiometry approach adopted here.) It is to be noted that ATP expended continually by RBCs (say, for homeostasis) has not been considered herein. Therefore, the source of vast majority of ATP found in RBC needs to be accounted from another pathway.

In order to explain the source of the excess ATP observed in RBC, we apply the murburn mechanistic perspective, which advocates constructive electron/moiety transfer roles for DROS. We propose (and provide ample evidence to argue) that $\mathrm{Hb}$ also serves as an enzyme (murzyme) that utilizes DROS dynamics to facilitate ATP production in RBC. We also provide data from reputed peers' publications and our own in silico studies to support our proposal and correlate it to clinically relevant pathologies like sickle cell anemia and thalassemia.

\section{Methods: Exploration of structure-function correlation of human respiratory globins}


The alpha monomer of human Hb-alpha (1SI4) (Sen et al., 2004) was first taken as a sample protein and its docking profile checked with a variety of ligands. Thereafter, monomers and tetramers of Hb-beta (6FQF) (Mazzarella et al., 2018), Hb-gamma (4MQJ) (Strader et al., 2014) and other relevant proteins' (1GZX, 3D17, 5E83, 1NQP, and 3RGK) deposited crystal structure coordinates were availed from Protein Data Bank. The structures were visualized with software such as Chimera 1.12 (Pettersen et al., 2004) and PyMol 1.3 (DeLano, 2002). Active site cavity was studied by POCASA 1.1 (Yu et al., 2010), keeping a probe radius of $2 \AA$, with a grid size of $1 \AA$ A. Small flexible molecules were docked to the large rigid proteins using AUTODOCK 4.2 (Forli et al., 2012), as per procedures reported in our earlier works (Manoj et al., 2019a). Literature search was conducted to collect data on binding affinities of relevant small molecules to $\mathrm{Hb} / \mathrm{Mb}$. We declare at the outset that we do not disclaim any experimental evidence reported for any other hypotheses in the field, and we approach the system with an ab initio parsimonious perspective, as enabled by computation-aided visual explorations.

\section{Results: Binding of adenosine nucleotides and phosphoglycerates to respiratory globins}

Figure 2 shows the structures of various molecules explored in this study, in particular: adult human hemoglobin-apha protein (1SI4), with the orientation of heme and the location of active site channel/cavity. Analyses of the active site volumes of the human respiratory globins with POCASA gave the values (in $\left.\AA^{3}\right)$ : $\mathrm{HbA}(1 \mathrm{SI} 4)=252, \mathrm{HbB}(3 \mathrm{D} 17)=239, \mathrm{HbF}(4 \mathrm{MQJ})=263$, $\operatorname{HbSA}(1 \mathrm{NQP})=281, \operatorname{HbSB}(1 \mathrm{NQP})=239, \operatorname{HbEA}(5 \mathrm{E} 83)=237, \operatorname{HbEB}(5 \mathrm{E} 83)=252, \mathrm{Mb}$ $(3 \mathrm{RGK})=196$. Table 1 presents the summary of in silico binding studies conducted herein. Significant depictions of high or low affinity interactions (for select tests and controls) are presented in the figures and discussed in the text.

Figure 3 shows that $\mathrm{HbA}$ has a low-affinity adenosine nucleotide docking site at the heme cavity aperture, with a binding energy term of $\sim-5 \mathrm{kcal} / \mathrm{mol}$, translating to a $\mathrm{K}_{\mathrm{d}}$ value of to $\sim 200 \mu \mathrm{M}$ $\left(\sim 10^{-4} \mathrm{M}\right)$. It can be seen that ADP presents itself quite favorably for phosphorylation, with the phosphate group enabling a facile presentation to the superoxide that could potentially release from distal end of heme center. From Table 1 and Figures $3 \& 4$, it can be seen that the ADP \& 
$\mathrm{NADH} / \mathrm{ATP}$ binding is relatively significant for the adult variants $(\alpha$ and $\beta$ ) of $\mathrm{Hb}$ in humans. However, sickle-cell and thalassemic $\mathrm{Hb}$ proteins showed relatively poor ADP-binding, although exhibiting significant affinities for ATP and NADH. The human fetal HbF and myoglobin (Mb) also showed significantly lower ADP-binding affinity, and Mb exhibited approximately three orders higher $\mathrm{K}_{\mathrm{d}}$ value than that of blood $\mathrm{Hb}$.

Figure 5 shows the docking of phosphoglycerates with hemoglobins. Quite interestingly, the small polar molecule of 2,3-bisphosphoglycerate or diphosphoglycerate (DPG/BPG) gave high affinity for binding at the heme pocket, and the energy terms were in the order $\mathrm{HbA} \sim \mathrm{HbB}>$ $\mathrm{HbF}>\mathrm{Mb}$. Using effective controls (1,3 BPG and other phosphoglycerates), it was discerned that this binding was not an artifact. The allosteric site for 2,3-BPG is known to bind via 'H2K82-H143' triad on the $\mathrm{Hb} \beta$ surface. This site gave a binding energy of $-9.35 \mathrm{kcal} / \mathrm{mol}\left(\mathrm{K}_{\mathrm{d}} \sim 140\right.$ $\mathrm{nM}$ ) in the normal $\mathrm{Hb} \alpha$, which was not higher than the active site affinity. In contrast, the sickle cell and thalassemic proteins presented relatively low active site binding (with respect to normal $\mathrm{Hb})$ and/or the beta monomers exhibited high allosteric affinity for 2,3-BPG.

Figure 6 and Table 2 show the results of 2,3-BPG and ADP docking to the tensed and relaxed tetrameric forms of $\mathrm{Hb}$. The relaxed form has an ultra-high affinity 2,3-BPG site that fits the central slot between the four monomers whereas the tensed form has a moderate-affinity ADP site (which is positioned adjacent to a 2,3-BPG high-affinity site) suitably posed to be attacked by DROS that could potentially emanate from beta-monomers' secondary apertures.

The survey of overall binding affinities across various monomers/tetramers gives a relative trend in the order of 2,3-BPG $>\mathrm{NADH}>\mathrm{ATP} \sim \mathrm{ADP}>\mathrm{AMP}$. 


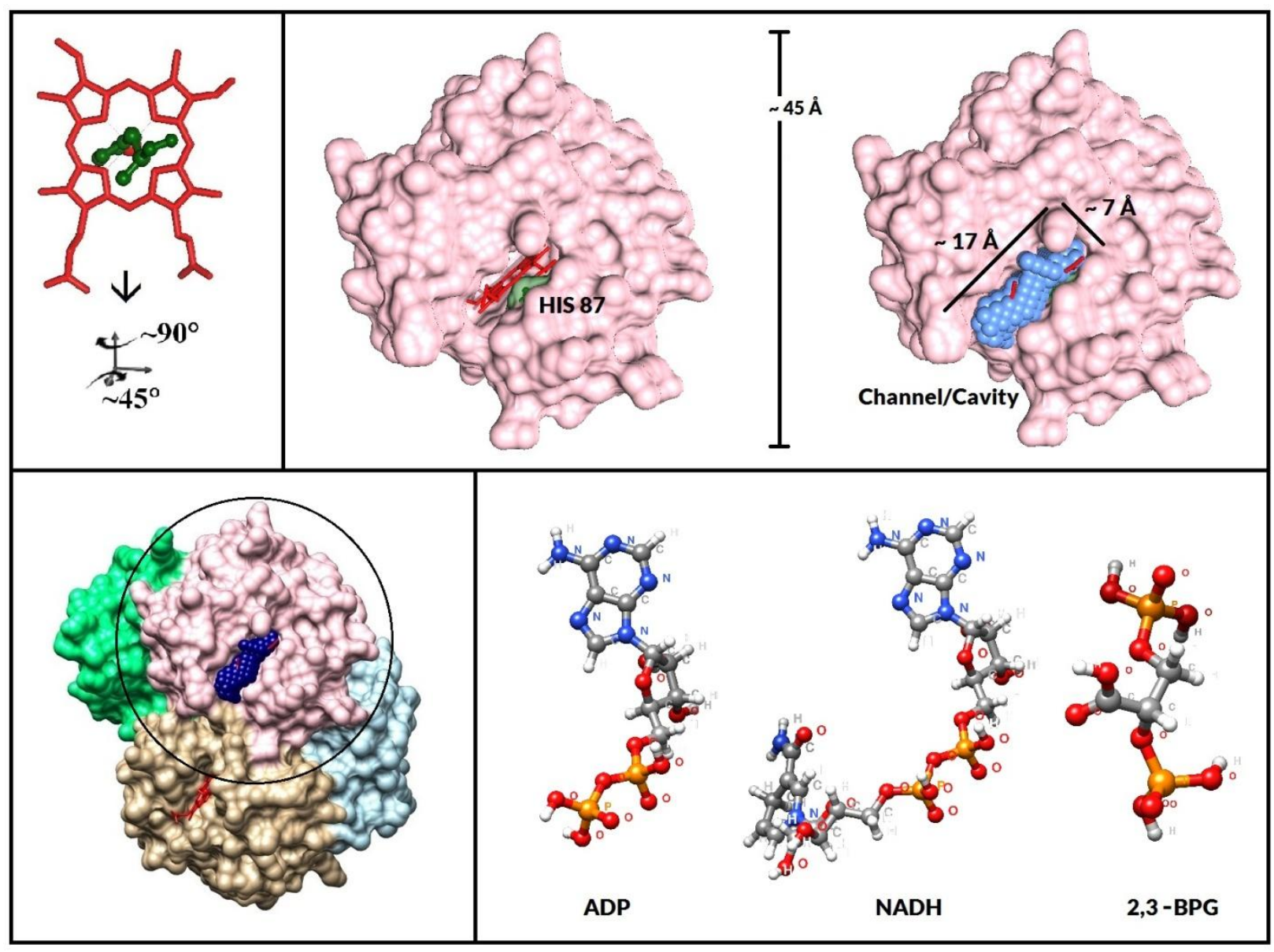

Figure 2: Structural features of hemoglobin Hb A (1SI4) The orientation and rotation of heme (for the monomeric depictions in bottom panels) is shown in the top-left panel, with the proximal histidine jutting out of the plane of paper. The top center panel depicts the hemoglobin monomer showing the solvent-accessible heme, with oxygen binding site of Fe atom shown in black (onto which oxygen binds, within the distal space) at the hemecenter. Unlike the relatively superficial proximal thiolate ligand of liver microsomal cytochrome P450s (Parashar \& Manoj, 2021), it can be seen that the proximal histidylate ligand of $\mathrm{Hb}$ is buried within the protein. The active site cavity per se is marked out (with POCASA) in the top right panel. The heme-ensconcing pouch is $\sim 12 \AA$ deep. The association of monomers into the tetramer (with the location of the active site cavity) is presented in the bottom-left panel. The structures of three key small molecules (explored in this study for interaction with $\mathrm{Hb}$ ) are shown in the bottom right panel. 


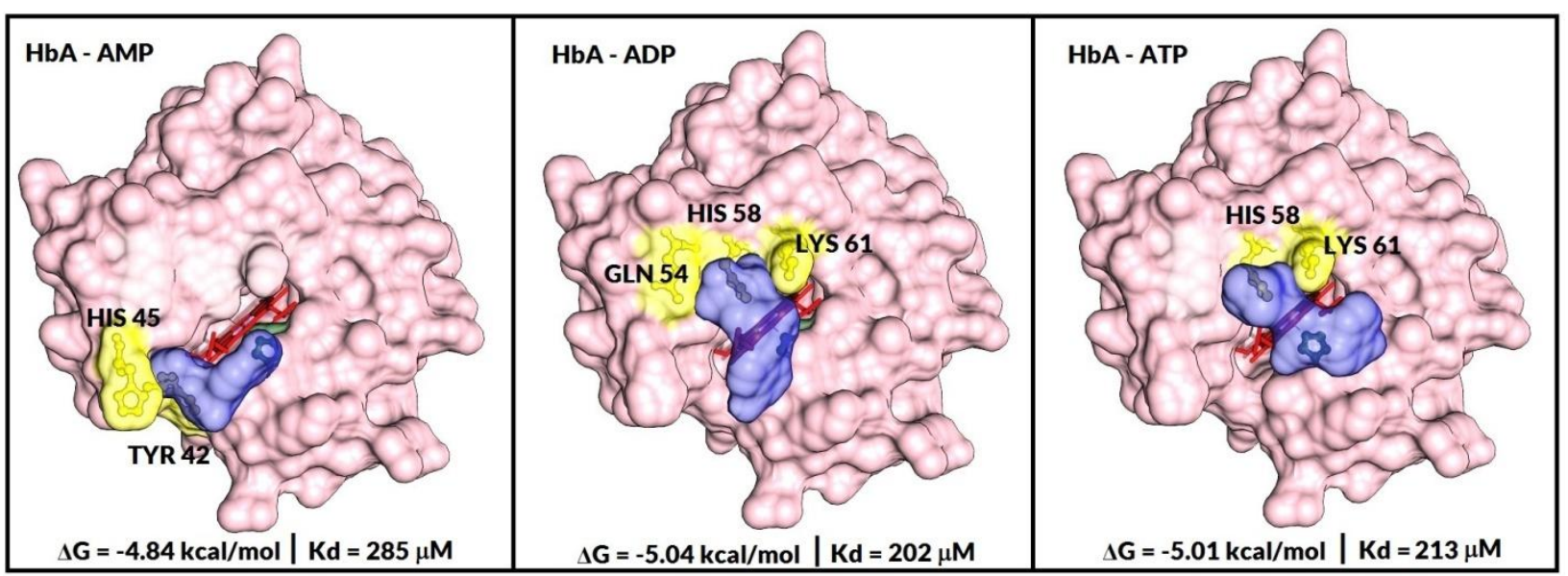

Figure 3: Docking of AMP/ADP/ATP to Hb-alpha (1SI4).

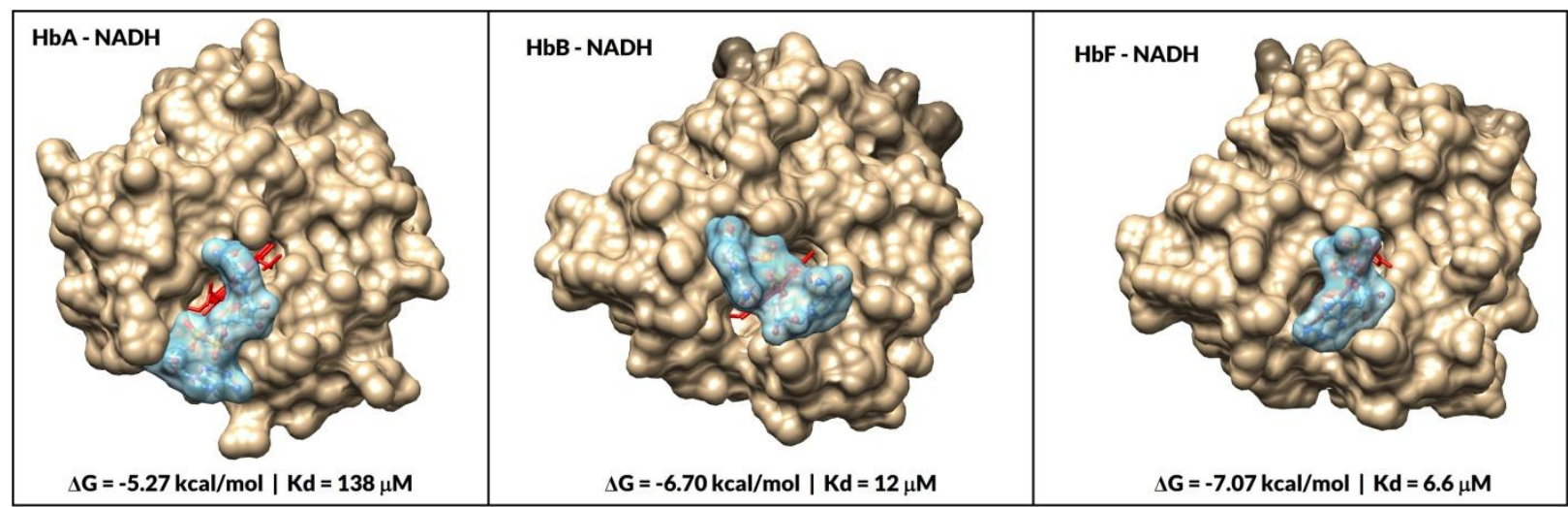

Figure 4: Docking of NADH to various monomers of human hemoglobin.

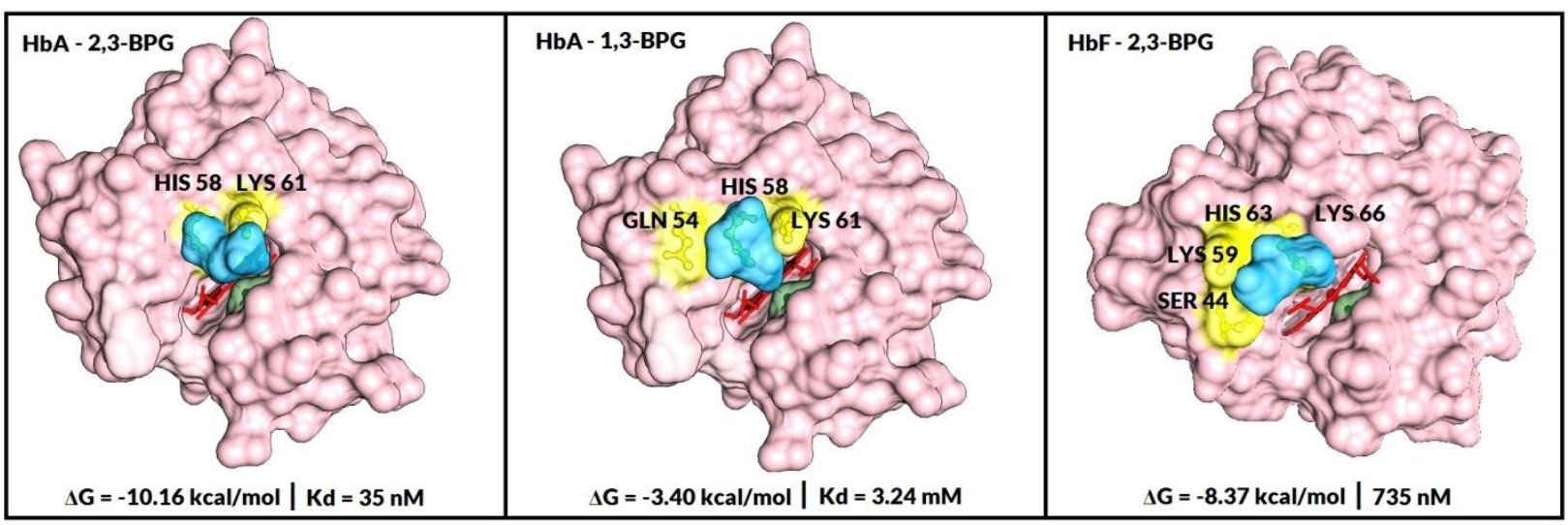

Figure 5: Docking of various phosphoglycerates to human Hb. 


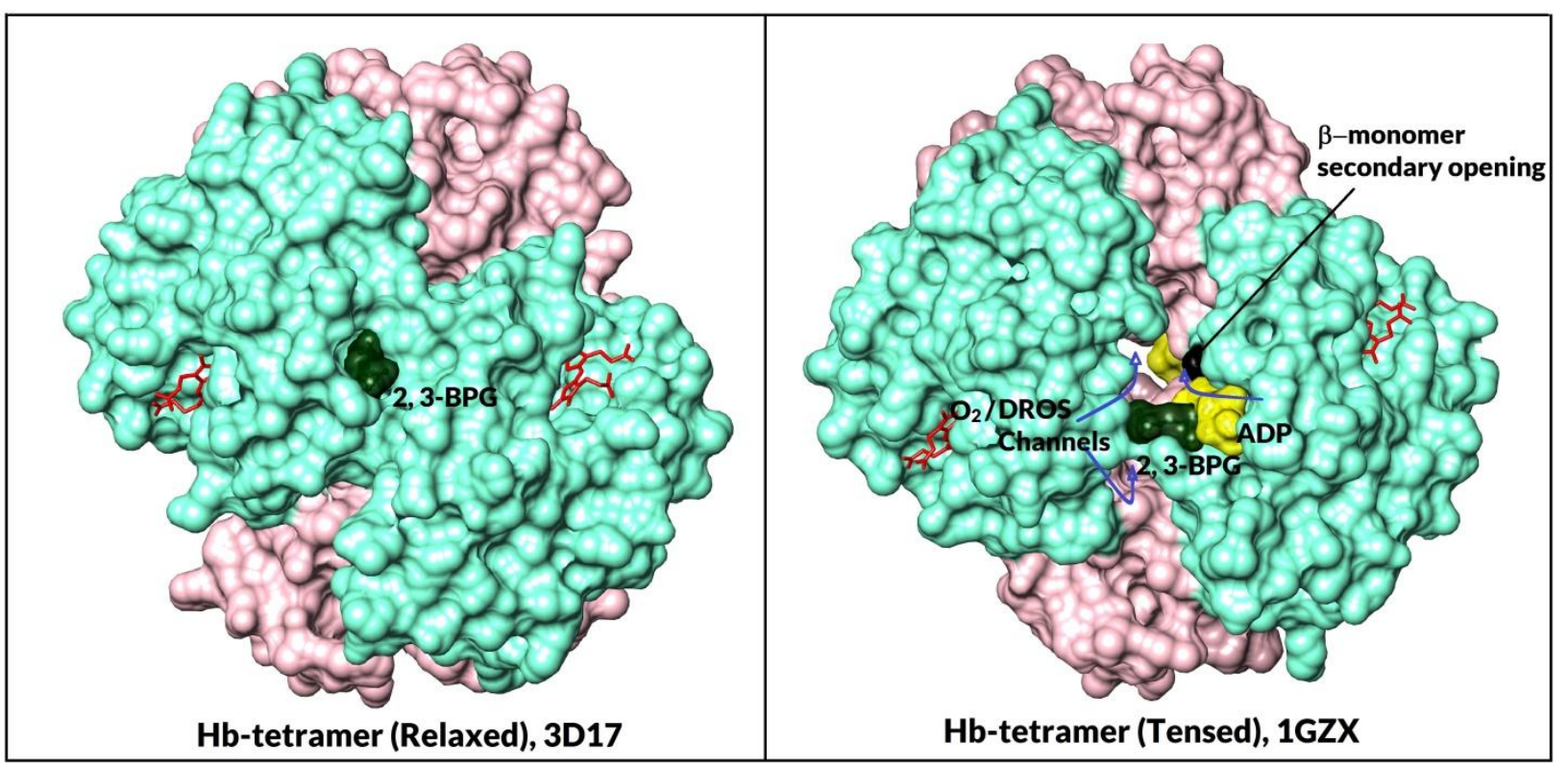

Figure 6: Interaction of tetramer with 2,3-BPG and/or ADP: Monomers of $\alpha$-hemoglobin are represented in pink and of $\beta$-hemoglobin in turquoise. Relaxed tetramer (PDB ID: 3D17) exhibits very strong affinity towards 2,3BPG (green) at the junction of the $\beta$-dimer but does not allow a strong bond with ADP, as shown in the left panel. The right panel shows the tensed state of hemoglobin with a fairly high affinity towards 2,3-BPG (green) and moderate affinity towards ADP (yellow). $\beta$-monomer has a secondary opening (circumference indicated in black) towards the $\mathrm{O}_{2}$ / DROS channel between the tetrameric junctions.

Table 1: Docking of respiratory globin monomers with adenosine nucleotides and phosphoglycerates

\begin{tabular}{|c|c|c|c|c|c|c|}
\hline No. & Monomer & Description & Ligand $^{\#}$ & $\begin{array}{c}\Delta \mathbf{G} \\
(\mathrm{kcal} / \mathrm{mol})^{*}\end{array}$ & $\mathrm{~K}_{\mathrm{d}}{ }^{*}$ & $\begin{array}{l}\text { Interacting Amino } \\
\text { Acids }\end{array}$ \\
\hline 1 & $\mathrm{HbA}(1 \mathrm{SI} \mid 4)$ & $\begin{array}{c}\alpha 2 \delta 2 \text { in } \mathrm{R} 2 \text { state bound } \\
\text { to } \mathrm{CN}\end{array}$ & 2,3-BPG & -10.16 & $35 n M$ & H58, K61 \\
\hline 2 & $\mathrm{HbA}(1 \mathrm{~S} \mid 4)$ & Ditto & $\mathrm{NADH}$ & $-5.27(-5.43)$ & $\begin{array}{c}138 \mu M \\
(104 \mu M)\end{array}$ & $\begin{array}{l}\text { Y42, H45, H58, } \\
\text { K90 }\end{array}$ \\
\hline 3 & HbA (1SI4) & Ditto & ATP & -5.01 & $213 \mu \mathrm{M}$ & H58, K61 \\
\hline 4 & HbA (1SI4) & Ditto & ADP (1) & -5.04 & $202 \mu \mathrm{M}$ & Q54, H58, K61 \\
\hline 5 & $\mathrm{HbA}(1 \mathrm{SI})$ & Ditto & AMP & -4.84 & $285 \mu \mathrm{M}$ & Y42, H45 \\
\hline 6 & $\mathrm{HbA}(1 \mathrm{SI} \mid 4)$ & Ditto & 1,3-BPG & $-3.40(-3.76)$ & $\begin{array}{c}3.24 \mathrm{mM} \\
(1.75 \mathrm{mM})\end{array}$ & Q54, H58, K61 \\
\hline 7 & $\mathrm{HbA}(1 \mathrm{SI})$ & Ditto & 3-PG & -3.63 & $2.20 \mathrm{mM}$ & Q54, H58, K61 \\
\hline 8 & HbA (1SI4) & Ditto & 2-PG & $-2.96(-3.51)$ & $\begin{array}{c}6.76 \mathrm{mM} \\
(2.68 \mathrm{mM})\end{array}$ & Q54, H58, K61 \\
\hline 9 & $\mathrm{HbA}(1 \mathrm{~S} \mid 4)$ & Ditto & $\mathrm{NAD}^{+}$ & -0.81 & $254 \mathrm{mM}$ & NA \\
\hline 10 & HbA (1SI4) & Ditto & NADPH & $-3.68(-4.64)$ & $\begin{array}{l}1.99 \mathrm{mM} \\
(397 \mu \mathrm{M})\end{array}$ & $\begin{array}{l}\text { T41, H45, K90, } \\
\text { L91 }\end{array}$ \\
\hline 11 & HbA (1SI4) & Ditto & $\mathrm{NADP}^{+}$ & +1.25 & NA & NA \\
\hline 12 & HbA (1GZX) & $\begin{array}{c}\alpha 2 \beta 2 \text { Tetra ligated with } \\
\mathrm{O}_{2} \text { (tensed) }\end{array}$ & 2,3-BPG & -9.88 & $57 \mathrm{nM}$ & Q54, H58, K61 \\
\hline 13 & HbA (1GZX) & Ditto & $\mathrm{NADH}$ & -6.66 & $13 \mu \mathrm{M}$ & A82, K90 \\
\hline 14 & HbA (1GZX) & Ditto & ATP & -5.16 & $165 \mu \mathrm{M}$ & K61 \\
\hline 15 & HbA (1GZX) & Ditto & ADP (1) & -4.31 & $695 \mu \mathrm{M}$ & Q54, H58, K61 \\
\hline
\end{tabular}




\begin{tabular}{|c|c|c|c|c|c|c|}
\hline 16 & HbA (1GZX) & Ditto & $\mathrm{NAD}^{+}$ & -1.80 & $48 \mathrm{mM}$ & K61 \\
\hline 17 & HbA (3D17) & $\begin{array}{c}\alpha 2 \beta 2 \text { Triply ligated with } \\
\text { CO (relaxed) }\end{array}$ & 2,3-BPG & -10.04 & $44 \mathrm{nM}$ & $\begin{array}{l}\mathrm{H} 45, \mathrm{Q} 54, \mathrm{H} 58, \\
\text { K61 }\end{array}$ \\
\hline 18 & $\mathrm{HbA}$ (3D17) & Ditto & $\mathrm{NADH}$ & -7.08 & $6.5 \mu \mathrm{M}$ & H45, H58, K61 \\
\hline 19 & $\mathrm{HbA}$ (3D17) & Ditto & ATP & -5.55 & $85 \mu \mathrm{M}$ & H45, H58, K61 \\
\hline 20 & HbA (3D17) & Ditto & ADP & -3.31 & $3.73 \mathrm{mM}$ & H45, K61 \\
\hline 21 & $\mathrm{HbA}$ (3D17) & Ditto & $\mathrm{NAD}^{+}$ & -1.95 & $38 \mathrm{mM}$ & K61 \\
\hline 22 & HbB (6FQF) & $\beta 4 \mathrm{Met} \mathrm{Hb}$ & 2,3 BPG & $\begin{array}{l}-10.15 \\
{[-9.35]}\end{array}$ & $\begin{array}{c}36 \mathrm{nM} \\
{[140 \mathrm{nM}]}\end{array}$ & K59, H63, K66 \\
\hline 23 & HbB (6FQF) & Ditto & $\mathrm{NADH}$ & -6.70 & $12 \mu \mathrm{M}$ & $\begin{array}{l}\text { K59, H63, K66, } \\
\text { K95 }\end{array}$ \\
\hline 24 & HbB (6FQF) & Ditto & ATP & -4.93 & $244 \mu \mathrm{M}$ & $\begin{array}{l}\text { S44, H63, K66, } \\
\text { K95 }\end{array}$ \\
\hline 25 & HbB (6FQF) & Ditto & $\operatorname{ADP}(1)$ & -4.73 & $343 \mu \mathrm{M}$ & K59, H63, K66 \\
\hline 26 & HbB (6FQF) & Ditto & $\mathrm{NAD}^{+}$ & -2.19 & $25 \mathrm{mM}$ & S44, K95 \\
\hline 27 & HbB (1GZX) & $\begin{array}{c}\alpha 2 \beta 2 \text { Tetra ligated with } \\
\mathrm{O}_{2} \text { (tensed) }\end{array}$ & 2,3-BPG & $\begin{array}{c}-9.31 \\
(-11.24)\end{array}$ & $\begin{array}{c}150 \mathrm{nM} \\
(5.73 \mathrm{nM})\end{array}$ & $\begin{array}{l}\text { S187, K202, } \\
\text { H206,K209 }\end{array}$ \\
\hline 28 & HbB (1GZX) & Ditto & $\mathrm{NADH}$ & -7.47 & $3.37 \mathrm{mM}$ & $\begin{array}{l}\text { S187, K202, H206, } \\
\text { K209 }\end{array}$ \\
\hline 29 & HbB (1GZX) & Ditto & ATP & -5.68 & $68.74 \mu \mathrm{M}$ & K209 \\
\hline 30 & HbB (1GZX) & Ditto & $\operatorname{ADP}(2)$ & -4.16 & $895 \mu \mathrm{M}$ & K238, L239 \\
\hline 31 & HbB (1GZX) & Ditto & $N A D^{+}$ & -1.62 & $65 \mathrm{mM}$ & $\mathrm{K} 238$ \\
\hline 32 & $\mathrm{HbB}$ (3D17) & $\begin{array}{l}\alpha 2 \beta 2 \text { Triply ligated with } \\
\text { CO (relaxed) }\end{array}$ & 2,3 BPG & $\begin{array}{c}-9.28 \\
(-10.04)\end{array}$ & $\begin{array}{l}159 n M \\
(44 n M)\end{array}$ & A62, K65, K66 \\
\hline 33 & HbB (3D17) & Ditto & $\mathrm{NADH}$ & -7.11 & $6.1 \mu \mathrm{M}$ & R40, S44, K95 \\
\hline 34 & HbB (3D17) & Ditto & ATP & -4.21 & $826 \mu \mathrm{M}$ & A62, K65, K66 \\
\hline 35 & HbB (3D17) & Ditto & $\operatorname{ADP}(1)$ & $-2.84(-4.0)$ & $\begin{array}{c}8.2 \mathrm{mM} \\
(1.2 \mathrm{mM})\end{array}$ & S44, K59, H63 \\
\hline 36 & HbB (3D17) & Ditto & $N A D^{+}$ & -1.8 & $48 \mathrm{mM}$ & S44, K59, S63 \\
\hline 37 & HbF (4MQJ) & $\alpha 4 \gamma 4 \mathrm{O}_{2}$ and $\mathrm{CO}$ bound & 2,3 BPG & -8.37 & $735 n M$ & $\begin{array}{l}\text { S44, K59, H63, } \\
\text { K66 }\end{array}$ \\
\hline 38 & HbF (4MQJ) & Ditto & $\mathrm{NADH}$ & -7.07 & $6.6 \mu M$ & S44, H63 \\
\hline 39 & HbF (4MQJ) & Ditto & ATP & -4.44 & $561 \mu \mathrm{M}$ & K66 \\
\hline 40 & HbF (4MQJ) & Ditto & $\operatorname{ADP}(1)$ & -3.82 & $1.58 \mathrm{mM}$ & H63, K66, K95 \\
\hline 41 & HbF (4MQJ) & Ditto & $\mathrm{NAD}^{+}$ & -1.84 & $45 \mathrm{mM}$ & H63, K66, K95 \\
\hline 42 & HbSA (5E83) & $\begin{array}{c}\alpha 2 \beta 2 \text { CO bound } \\
\text { tetrameric sickle cell }\end{array}$ & 2,3 BPG & -10.95 & $9.3 n M$ & $\begin{array}{l}\mathrm{H} 45, \mathrm{Q} 54, \mathrm{H} 58, \\
\mathrm{~K} 61\end{array}$ \\
\hline 43 & HbSA (5E83) & Ditto & $\mathrm{NADH}$ & -6.30 & $24 \mu M$ & Q54, H58, K61 \\
\hline 44 & HbSA (5E83) & Ditto & ATP & -6.63 & $13.9 \mu M$ & Q54, K61 \\
\hline 45 & HbSA (5E83) & Ditto & $\operatorname{ADP}(1)$ & -3.97 & $1.22 \mathrm{mM}$ & Q54, H58, K61 \\
\hline 46 & HbSB (5E83) & Ditto & 2,3 BPG & $\begin{array}{l}-10.18 \\
(-10.92)\end{array}$ & $\begin{array}{c}35 n M \\
(10 n M)\end{array}$ & K59, H63, K66 \\
\hline 47 & HbSB (5E83) & Ditto & $\mathrm{NADH}$ & -8.89 & $305 n M$ & $\begin{array}{l}\text { S44, K59, H63, } \\
\text { K66, T87 }\end{array}$ \\
\hline 48 & HbSB (5E83) & Ditto & ATP & -5.72 & $64.4 \mu \mathrm{M}$ & S44, K66 \\
\hline 49 & HbSB (5E83) & Ditto & $\operatorname{ADP}(2)$ & -4.36 & $638 \mu \mathrm{M}$ & $\begin{array}{l}\text { K66, D73, T84, } \\
\text { T87 }\end{array}$ \\
\hline 50 & HbEA (1NQP) & $\begin{array}{l}\alpha 2 \beta 2 \mathrm{CN} \text { bound } \\
\text { tetrameric } \\
\text { thalassemic cell }\end{array}$ & 2,3 BPG & -9.66 & $83 n M$ & $\begin{array}{l}\mathrm{H} 45, \mathrm{H} 58, \mathrm{~K} 61 \\
\mathrm{~K} 90\end{array}$ \\
\hline
\end{tabular}




\begin{tabular}{|c|c|c|c|c|c|c|}
\hline 51 & HbEA (1NQP) & Ditto & $\mathrm{NADH}$ & -6.08 & $34.9 \mu M$ & $\mathrm{H} 45, \mathrm{~K} 61, \mathrm{~A} 82$ \\
\hline 52 & HbEA (1NQP) & Ditto & ATP & -5.53 & $89 \mu M$ & H58, K61 \\
\hline 53 & HbEA (1NQP) & Ditto & $\operatorname{ADP}(2)$ & $\begin{array}{l}-4.08 \\
(-4.61)\end{array}$ & $\begin{array}{l}1.02 \mathrm{mM} \\
(417 \mu \mathrm{M})\end{array}$ & H58, K61, K90 \\
\hline 54 & HbEB (1NQP) & Ditto & $2,3 \mathrm{BPG}$ & $\begin{array}{c}-9.47 \\
(-12.09)\end{array}$ & $\begin{array}{c}114 \mathrm{nM} \\
(1.4 \mathrm{nM})\end{array}$ & $\begin{array}{l}\text { S44, K59, H63, } \\
\text { K66 }\end{array}$ \\
\hline 55 & HbEB (1NQP) & Ditto & NADH & -7.44 & $3.5 \mu \mathrm{M}$ & S44, H63, K66 \\
\hline 56 & HbEB (1NQP) & Ditto & ATP & $\begin{array}{c}-4.22 \\
(-5.31)\end{array}$ & $\begin{array}{c}802 \mu \mathrm{M} \\
(128 \mu \mathrm{M})\end{array}$ & S44, K66 \\
\hline 57 & HbEB (1NQP) & Ditto & ADP (1) & $\begin{array}{l}-3.62 \\
(-3.71)\end{array}$ & $\begin{array}{c}2.23 \mathrm{mM} \\
(1.91 \mathrm{mM})\end{array}$ & K59, H63, K66 \\
\hline 58 & Mb (3RGK) & Aquomet form & $2,3 \mathrm{BPG}$ & -7.91 & $1.6 \mu M$ & $\begin{array}{l}\text { R45, K63, H64, } \\
\text { T67 }\end{array}$ \\
\hline 59 & Mb (3RGK) & Ditto & $\mathrm{NADH}$ & $\begin{array}{l}-5.66 \\
(-6.14)\end{array}$ & $\begin{array}{l}71.5 \mu \mathrm{M} \\
(32 \mu \mathrm{M})\end{array}$ & R45, H64, T67 \\
\hline 60 & Mb (3RGK) & Ditto & ATP & $\begin{array}{l}-3.77 \\
(-4.17)\end{array}$ & $\begin{array}{c}1.74 \mathrm{mM} \\
(870.5 \mu \mathrm{M})\end{array}$ & R45, K63, T67 \\
\hline 61 & Mb (3RGK) & Ditto & ADP & $\begin{array}{c}-2.38 \\
(-2.90)\end{array}$ & $\begin{array}{c}17.9 \mathrm{mM} \\
(7.42 \mathrm{mM})\end{array}$ & R45, H64, T67 \\
\hline 62 & Mb (3RGK) & Ditto & 1,3 BPG & $\begin{array}{l}-3.20 \\
(-4.02)\end{array}$ & $\begin{array}{c}4.52 \mathrm{mM} \\
(1.12 \mathrm{mM})\end{array}$ & R45, H64, T67 \\
\hline 63 & Mb (3RGK) & Ditto & $\mathrm{NAD}^{+}$ & +0.56 & NA & NA \\
\hline 64 & Mb (3RGK) & Ditto & $\mathrm{NADPH}$ & $\begin{array}{c}-4.45 \\
(-5.27)\end{array}$ & $\begin{array}{c}543 \mu \mathrm{M} \\
(138 \mu \mathrm{M})\end{array}$ & R45, H64, T67 \\
\hline 65 & Mb (3RGK) & Ditto & NADP $^{+}$ & Nil & $\mathrm{Nil}$ & $\mathrm{Nil}$ \\
\hline
\end{tabular}

Table 2: Extra-heme pocket binding of select ligands to tetrameric $\mathrm{Hb}$.

\begin{tabular}{|c|c|c|c|c|c|c|}
\hline No. & Protein & Description & Ligand & $\Delta \mathrm{G}(\mathrm{kcal} / \mathrm{mol})^{\#}$ & $\mathrm{~K}_{\mathrm{d}}^{\#}$ & $\begin{array}{l}\text { Interacting Amino } \\
\text { Acids }\end{array}$ \\
\hline 1 & $\mathrm{Hb}(1 \mathrm{GZX})$ & $\begin{array}{l}\alpha 2 \beta 2 \text { Tetra } \\
\text { ligated with } \mathrm{O}_{2} \\
\text { (tensed) }\end{array}$ & $\begin{array}{c}2,3-B P G \\
(4+1)\end{array}$ & -16.12 & $1.53 p M$ & $\begin{array}{l}\text { V544, H545, K625, } \\
\text { G679, N682 }\end{array}$ \\
\hline 2 & Hb (1GZX) & Ditto & $\begin{array}{l}\text { ADP } \\
(4+1)\end{array}$ & -5.65 & $72 \mu M$ & V544, L621, K625 \\
\hline 3 & Hb (3D17) & $\begin{array}{l}\alpha 2 \beta 2 \text { Triply } \\
\text { ligated with CO } \\
\text { (relaxed) }\end{array}$ & $\begin{array}{c}2,3-B P G \\
(4+2)\end{array}$ & $\begin{array}{l}-20.75 \\
-12.54\end{array}$ & $\begin{array}{l}619 a M, \\
638 p M\end{array}$ & K82, H143, H146 \\
\hline 4 & $\mathrm{Hb}$ (3D17) & Ditto & $\begin{array}{l}\text { ADP } \\
(4)\end{array}$ & Nil & Nil & Nil \\
\hline
\end{tabular}

${ }^{\#}$ Bold values in parentheses represent heme pocket binding.

Discussion: Placing our findings/proposals with respect to available literature 
Several works have explored the implications or DROS in hemoglobin/RBC physiology (Ellsworth et al., 2016; Ellsworth et al., 2006; Sprague et al., 2009; Ellsworth and Sprague, 2012; Sprague et al., 2010; Turpin et al., 2020). There is also speculation that human skeletal muscle blood flow as well as tissue oxygen delivery is dependent on circulating ATP concentrations (González-Alonso et al., 2002). In the light of our earlier works, the literature such as above and the findings herein could be amalgamated with a fresh perspective, to give greater insights to better understand several physiological scenarios and pathological states.

Over the last several decades, experimental evidence for adenosine nucleotides' (like ADP and $\mathrm{NADH}$ ) binding to hemoglobin (using equilibrium dialysis, UV-Vis and NMR spectroscopy, etc.) have been reported by several groups (Banerjee et al., 2012; Cashon et al., 1986; Gupta et al., 1978; Lo and Schimmel, 1969; Ogo et al., 1989; Peng et al., 2003). The order of affinity, as determined by equilibrium dialysis (a suitable technique to study association-dissociation phenomena) is BPG>ATP>ADP>AMP, and the pioneering researchers had suggested that they bind at the same locus (Lo and Schimmel, 1969). The in silico binding energy values determined in this study for the heme cavity gave the order of affinity as $B P G>A D P \geq A T P>A M P$. Since there were 3 distinct clusters for ATP binding (compared to one of ADP), the net outcome obtained with in silico explanation is quite similar to the one observed with equilibrium dialysis. Therefore, our in silico exploration results are valid and also justify the pioneers' deduction that the small molecule ligands bind at the same site. In most cases, the binding affinity of ADP/ATP/NADH/2,3-BPG to the proteins of interest is relevant with respect to the physiological concentrations of the small molecules. Although the binding of adenosine nucleotides to $\mathrm{Hb}$ or $\mathrm{Mb}$ (Inohara et al., 2013) was known, their effects were attributed to allostery and the 'cause-consequence correlations' were not drawn with adequate physiological relevance. This is when other salient protagonists like $\mathrm{H}^{+}+\mathrm{CO}_{2}$ (Bohr Effect) were wellexplored with respect to $\mathrm{Hb}$ function.

\section{Murburn model for transport/metabolism mediated/catalyzed by hemoglobin}

Murburn concept advocates that certain redox enzymes can mediate catalysis via $\mathrm{DR}(\mathrm{O}) \mathrm{S}$ stabilized and released from one site, on a substrate bound at another site on/around the enzyme. 
We posit that hemoglobin is a murzyme, working along murburn concept. Since the majority of ATP formed in RBC must stem from alternative metabolic routes (that relies on the conversion of glucose), we propose that it is synthesized from the NADH formed in the $6^{\text {th }}$ step, from glyceraldehyde-3-phosphate (catalyzed by the enzyme glyceraldehyde phosphate dehydrogenase). As per the murburn perspective, MetHb reductase, also known as diaphorase or cytochrome $b_{5}$ reductase (Kitao et al., 1974), could activate oxygen to give superoxide, along the lines established for cytochrome-reducing flavoenzymes (Manoj et al., 2010). The superoxide thus formed could directly bind hemoglobin. Else, $\mathrm{DR}(\mathrm{O}) \mathrm{S}$ may relay the electron to the hemeFeIII (as the heme is accessible to solvent) and reduce it to hemeFeII, after which an oxygen molecule can access and bind it at the distal side. The two probabilistic events give the same outcomes. The association of oxygen to hemeFeII $\left(k_{\mathrm{on}}=6.6 \times 10^{7} \mathrm{M}^{-1} \mathrm{~s}^{-1}\right)$ and dissociation thereof $\left(k_{\mathrm{off}}=2 \times 10^{1} \mathrm{~s}^{-1}\right)$ are well characterized (Wilbur et al., 2012). It implies that the coordinate-ligated complex has a $\mathrm{K}_{\mathrm{d}}$ of $\sim 313 \mathrm{nM}$ and dissociates $\sim 20$ times per second. Quite similar to the association event, the dissociation event can occur either via "FeIII + superoxide" or "FeII + oxygen". In case of the former outcome, the hemeFe needs to be re-reduced; and the superoxide released would set off a murburn phosphorylation cascade near the Hb protein, leading to DROS/oxygen, ATP and water as products. (DROS like peroxide or superoxide would auto or catalytically dismutate or cross-react, to regenerate oxygen, which can be used by cells. This would facilitate oxygen-superoxide binding in the other $\mathrm{Hb}$ molecules within vicinity, explaining the cooperativity. In case the latter dissociation occurs, oxygen can be availed by tissues and the hemeFe is ready to bind another molecule of oxygen yet again. In fact, the nature of the oxy-Hb adduct is a mixture of both, with $\mathrm{Fe}(\mathrm{III})-{ }^{*} \mathrm{O}_{2}{ }^{-}$superseding $\mathrm{Fe}(\mathrm{II})-\mathrm{O}_{2}$ populations in the ratio of $3: 1$ to $4: 1$, as indicated by DFT calculations, reactivity profiles and spectroscopic studies (Jensen \& Ryde, 2004). Therefore, our proposal that superoxide could emanate from the heme center is probabilistically/statistically viable. At low acidity and low 2,3-BPG concentrations, the high affinity 2,3-BPG sites (with $\mathrm{pM}$ level $\mathrm{K}_{\mathrm{d}}$ ) within the tetramer are occupied in the oxygenated $\mathrm{Hb}$ (with relaxed monomers). In this state, the escape of oxygen/superoxide via the secondary aperture of beta-monomers can be minimized and the primary cavities of the monomers are also bound to ATP/NADH, preventing oxygen loss via dissociation. This serves $\mathrm{Hb}$ well in its $\mathrm{O}_{2}$-transport function. At higher acidity and higher concentrations of 2,3-BPG (which is correlated to lower concentration of NADH/ATP), the 
primary heme active sites' access of 2,3-BPG becomes more facile and relevant; and $\mathrm{Hb}$ 's transportation of oxygen ends and metabolic role is discharged. Now, oxygen/DROS are displaced from the active site, and DROS dynamics is facilitated around the $\mathrm{Hb}$ monomers. The moderate affinity ADP bound at the central slot of the tensed tetramer serves as a highly efficient modality for attack by the DROS that could potentially emerge from the secondary aperture of the beta-monomers. Therefore, the secondary aperture of beta-monomer (Figure 7) enhances efficient oxygen/DROS delivery and inter-monomer communication (which is the same as the erstwhile concept of co-operativity). The overall murburn scheme is depicted in Figure 8 and supported by the following features of $\mathrm{Hb} / \mathrm{RBC}$ :

1. When superoxide was presented to RBC (via xanthine oxidase activity in situ) enhanced ATP production/release was observed alongside increased DROS production (Ellsworth et al., 2006). This is direct and corroborative evidence for our proposal, which is identical to the ATP synthesis afforded by in situ provisions of xanthine oxidase activity in the mitochondrial system (Mailer, 1990). We had earlier demonstrated that superoxide can aid ATP synthesis in vitro (with just ADP and phosphate), and provided luciferase activity-based (Manoj et al., 2019a) and HPLC-based (Manoj et al., 2019b) confirmation for the feasibility of DROS-mediated ATP synthesis under physiological ambiances.

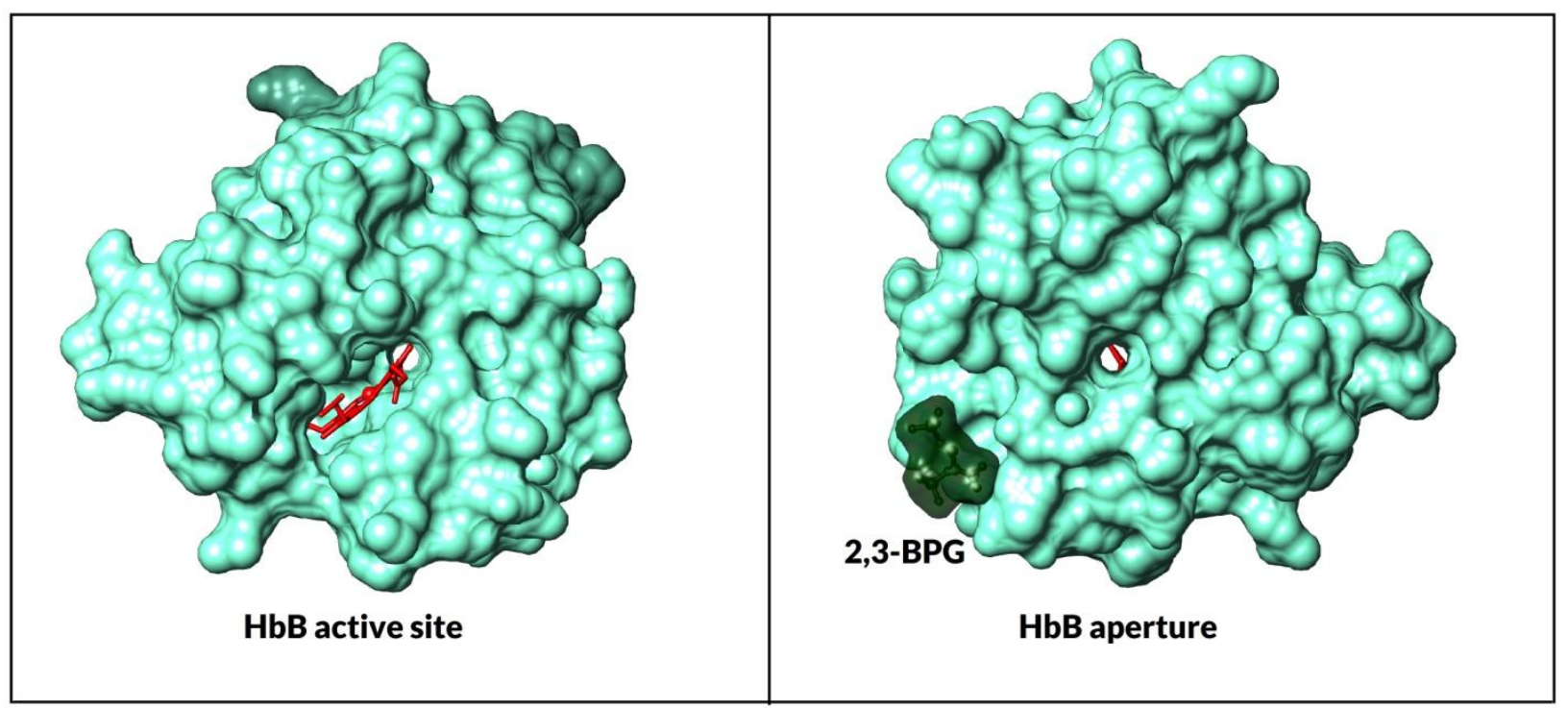

Figure 7: Structure of the beta monomer of human hemoblogin shows a secondary heme cavity aperture. 


\section{Overview}

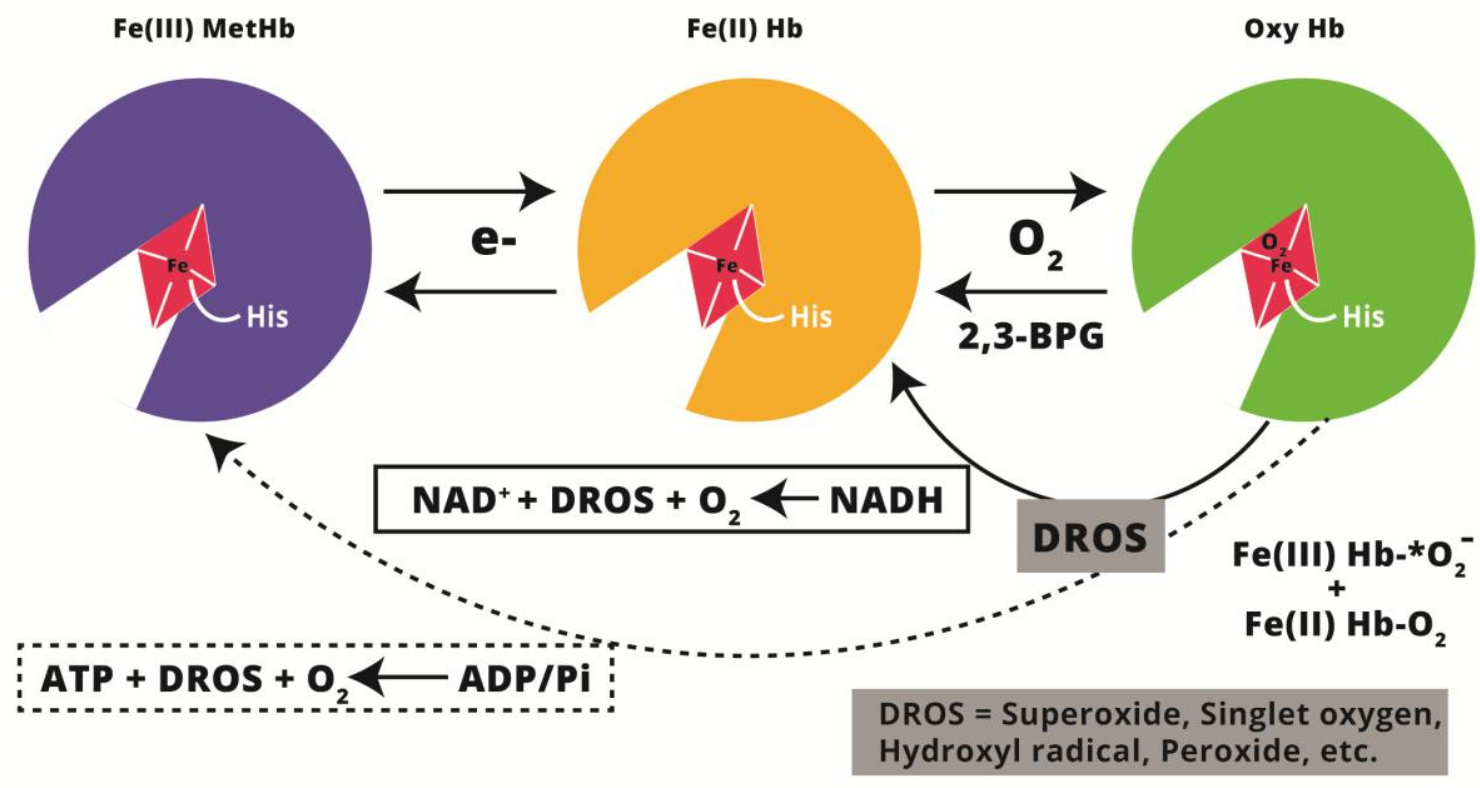

\section{Low 2,3-BPG and high $\mathrm{pH}$ (Relaxed)}

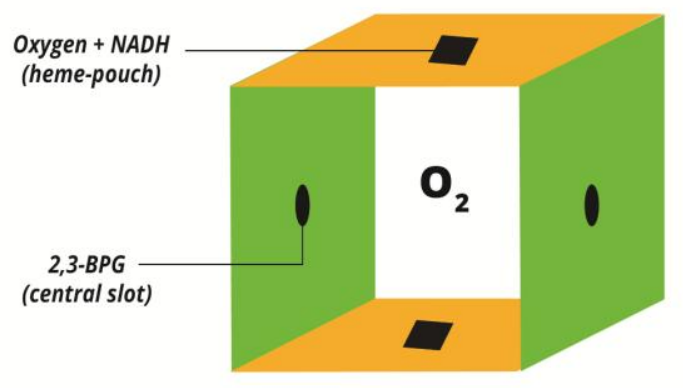
Two high affinity 2,3-BPG sites occupied; Heme-pouch binding of NADH; oxygen retained efficiently at heme pouch.

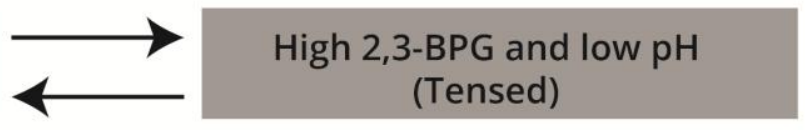

\section{Transport of oxygen by $\mathrm{Hb}$}

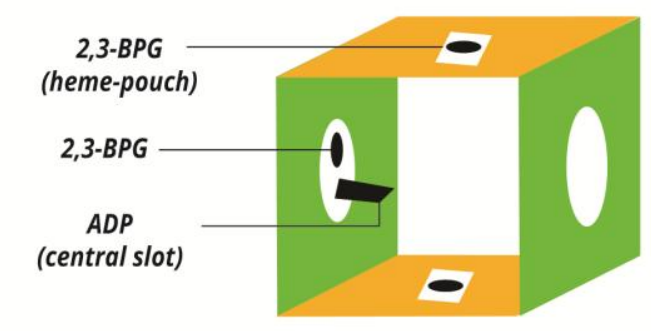
2,3-BPG binds heme pouch and oxygen detaches; $A D P$ binds to central slot, aided by 2,3-BPG;
Oxygen and DROS dynamics enabled.

\section{Metabolism of oxygen by $\mathrm{Hb}$}

Figure 8: The murburn perspective for $\mathbf{H b}$-sponsored physiology (roles of proton and water not shown). For enabling facile depiction, the two alpha and two beta monomers are considered equivalent to the opposing faces of a cube. (This has no realistic bearing with the actual structure!) For clarity, the heme pouches of beta monomer are not shown. The tetramer may shift shapes to intermediary structures, with varying affinities for the ligands. The schematic depiction shows effective ligand/structure aided confinement of oxygen for transport (left) and ligand/aperture aided $\mathrm{O}_{2}$ /DROS delivery (right). 
2. The thermodynamic/kinetic and mechanistic aspects of the overall murburn reaction schemes have been discussed in our earlier works (Manoj et al., 2019a,b; Manoj \& Bazhin, 2019). The murburn equation for ATP synthesis from NADH can be minimally represented theoretically as:

$$
\begin{gathered}
\mathrm{NADH}+\mathrm{H}^{+}+\mathrm{O}_{2}+\mathrm{nADPOH}+\mathrm{nPOH} \rightarrow \mathrm{NAD}+\mathbf{n A D P O P}+\mathbf{n H}_{2} \mathrm{O}+\mathrm{H}_{2} \mathrm{O}_{2} \\
\text { For } \mathrm{n}=1, \Delta_{\mathrm{r}} G^{\mathrm{o}}{ }_{\mathrm{aq}}=-546 \mathrm{~kJ} / \mathrm{mol}, \text { or } \mathrm{K}_{\mathrm{eq}}=\sim 10^{96}
\end{gathered}
$$

It can be envisaged that the depletion of DROS in milieu due to catalase/SOD activity in RBC and the continuous ATP-consumption by various life-activities would drive the equilibrium to the right. Though the depletion of catalytically essential DROS would lower ATP yields, this strategy would be essential to minimize collateral cellular damage, to afford longer life-spans. Given the scenario above, we can envisage a fractional yield of the useful DROS reactions from the theoretical maximum. Let's say we get $\mathrm{K}_{\mathrm{eq}} \sim 10^{9} \mathrm{M}^{-1}$ for the equation/equilibrium above. Since $\mathrm{K}_{\mathrm{eq}}\left(\mathrm{M}^{-1}\right)=\left(\left[\mathrm{NAD}^{+}\right] \times[\mathrm{ATP}] \times\left[\mathrm{H}_{2} \mathrm{O}\right] \times\left[\mathrm{H}_{2} \mathrm{O}_{2}\right]\right) /\left([\mathrm{NADH}] \times\left[\mathrm{H}^{+}\right] \times\left[\mathrm{O}_{2}\right] \times[\mathrm{ADP}] \times[\mathrm{Pi}]\right)$, we can solve the equation for the equilibrium theoretical yield of [ATP] by substituting the ascertained values of reactants/metabolites in erythrocytes $\left(\left[\mathrm{NADH} \approx \mathrm{NAD}^{+}\right]=\left[\mathrm{O}_{2}\right]=[\mathrm{ADP}]=\right.$ $\left.10^{-4} \mathrm{M} ;[\mathrm{Pi}]=10^{-3} \mathrm{M}\right)$ as below:

$$
\begin{aligned}
{[\mathrm{ATP}] } & =\mathrm{K}_{\mathrm{eq}} \times\left([\mathrm{NADH}] \times\left[\mathrm{H}^{+}\right] \times\left[\mathrm{O}_{2}\right] \times[\mathrm{ADP}] \times[\mathrm{Pi}]\right) /\left(\left[\mathrm{NAD}^{+}\right] \times\left[\mathrm{H}_{2} \mathrm{O}\right] \times\left[\mathrm{H}_{2} \mathrm{O}_{2}\right]\right) \\
& =\sim 10^{9} \times\left(\left[\sim 10^{-4}\right]\left[10^{-7}\right]\left[10^{-4}\right]\left[10^{-4}\right]\left[10^{-3}\right]\right) /\left(\left[\sim 10^{-4}\right]\left[10^{1}\right]\left[10^{-10}\right]\right) \\
& =\sim 10^{9} \times\left(\sim 10^{-22}\right) /\left(\sim 10^{-13}\right)=10^{0}=1 \mathrm{M} ! !
\end{aligned}
$$

It can be seen that even with a fraction of the overall yield (and with water and peroxide concentrations respectively taken as $10 \mathrm{M}$ and $0.1 \mathrm{nM}$ ), the ATP formation overshoots the expectations by three orders of magnitude! Therefore, the murburn phosphorylation equation involving the intermediacy of DROS is highly efficient, and the product concentrations can be comfortably explained in thermodynamic/equilibrium treatments. Also, since the reactions involve bimolecular collisions (involving radicals that pose low activation energy barriers), the overall reactions are also probabilistically, kinetically and mechanistically facile.

3. Direct EPR-spectroscopic evidence is available for the release of superoxide from hemoglobin (Balagopalakrishna et al., 1996). Owing to the high concentrations of hemeFe, catalase, peroxiredoxins, SOD, etc. (which is expected to efficiently deplete DROS found away from $\mathrm{Hb}$, to levels below temporal and measurable detection-ability), the online detected peroxide 
concentrations would be low. In spite of the high concentrations of such enzymes, DROS have been detected in RBCs (Giulivi et al., 1994; Novak et al., 1998; Scarpa et al., 2011; Schacter, 1986; Song et al., 2015). It is important to note that catalases and peroxidases produce ROS depending on the reaction conditions and these enzymes do not have strictly antioxidant functions. For example: catalase also serves as an oxidase (Vetrano et al., 2005). Similarly, hemoglobin also performs oxidative reactions (Winterbourn, 1990).

4. Superoxide mediated phosphorylation of ADP would be facile in the vicinity of $\mathrm{Hb}$, as shown by molecular docking (Figure 3). In this regard, binding of NADH (present at relatively lower concentrations) at the heme-aperture could also facilitate DROS-dynamics in milieu, enabling efficient ATP synthesis and sequential/concerted oxygen or superoxide binding/utilization by the $\mathrm{Hb}$ tetramer. In this regard, the binding of ADP (Lo \& Schimmel, 1969) and NADH (Cashon et al., 1986) to $\mathrm{Hb}$ have been substantiated with earlier research reports from reputed labs.

5. Experimental/theoretical evidence for the predominance and relevance of heme $\mathrm{Fe}(\mathrm{III})$ superoxide type adduct population is available in literature (Jensen \& Ryde, 2004). If we consider that $\mathrm{Hb}$ is present at $\sim 5 \mathrm{mM}\left(\sim 2 \times 10^{8}\right.$ copies $)$ in $\mathrm{RBC}$, and account that the naturally found $\sim 1 \%$ MetMb are formed by dissociation via the former modality (FeIII-superoxide), we have a working Hb-murzyme concentration of $50 \mu \mathrm{M}\left(\sim 2 \times 10^{6}\right.$ copies $)$. For a comparison, this is twice the concentration of the most abundant of glycolytic enzymes (which form only 2\% of the total protein content) of RBC, glyceraldehyde-3-phosphate dehydrogenase, which makes NADH at the $6^{\text {th }}$ step (Bryk and Wiśniewski, 2017). Also, the same authors in their exhaustive proteomics study above had reported that redox enzymes- catalase, peroxiredoxins, and superoxide dismutase (SOD) were the other proteins present in copy numbers ranging in millions. The presence of these enzymes signifies the high relevance of DROS production and involvement in RBCs. It must be remembered that the presence of cutting boards, knife-racks and gloves (analogous to SOD/catalase/peroxidase, glutathione, peroxiredoxins, etc.) in the kitchen (analogous to RBCs) do not signify the irrelevance of knives (analogous to DROS), but it is an indication of the routine relevance/utility of knives (Jacob and Manoj, 2019). 
6. Hb-Fe needs to be reduced by a flavoenzyme (which must be supported by NADH, in turn) for binding oxygen and both NADH and flavoenzyme cytochrome reductase are present in RBCs. (If hemeFeIII or MetHb could directly bind and transport oxygen, then it would have made sense to argue that murburn mechanism would not be physiologically relevant.). Further, the concentrations of components (proteins, NADH, ADP, Pi, $\mathrm{O}_{2}$, etc.) in RBCs (Garrett and Grisham, 1999) are conducive for murburn chemistry (Manoj et al., 2016; Parashar and Manoj, 2021); (Manoj et al., 2019a; Manoj et al., 2020; Manoj et al., 2019b), in spite of the water-filled and larger dimensions of the RBC. Particularly, since the oxidative phosphorylation route depends on $\mathrm{mM}$ levels of inorganic phosphate (which is available in $\mathrm{RBC}$ ), the formation of $\mathrm{mM}$ levels of ATP by this route seems more probable (when contrasted to the highly regulated substrate-level phosphorylations whose intermediates are in $\mu \mathrm{M}$ ranges).

\section{What are some salient facts/observations that murburn proposal explains better?}

Visualizations, data and interpretations from the current in silico explorations (in conjunction with murburn concept) allow for several novel explanatory paradigms in the field, pertaining to the energy metabolism in RBCs and oxygen delivery by $\mathrm{Hb}$.

1. DROS-assisted formation of ATP in RBC can potentially explain the $\mathrm{mM}$ concentration ranges of ATP when ADP is less than one tenth of the same (Garrett \& Grisham, 1999). Also, the long life of circulating erythrocytes ( $\sim$ months) carrying out various functions ( $\mathrm{Lu}$ et al., 2008; Pandey and Rizvi, 2011), without nucleus or mitochondria, is explained with Hb serving as an agent of ATP synthesis. The current binding energy analyses suggest that Mb has far lower functional relevance for interaction with ADP, when compared to $\mathrm{Hb}$. This could be explained by considering the fact that myocytes have mitochondria to generate high concentrations of ATP.

2. How does hemoglobin get reduced? The concentration of MetHb/Cyt. $b_{5}$ reductase is very low, which precludes the protein-protein complexation based long-range electron transfer process (Yubisui et al., 1980). We have already explained the rationale for murburn model of electron transfers in several heme-flavin protein systems (Manoj et al., 2016a-c). The positively 
charged amino acid residues at the heme pouch entrance serve to attract negatively charged species like superoxide and phosphate ions.

3. Tetrameric nature of $\mathrm{Hb}$ would favor radical scavenging by the neighboring monomer, which could also explain the sigmoid binding of oxygen that could result from the superoxide binding dynamics, as seen in P450 systems (Harlow and Halpert, 1998; Manoj et al., 2016a). The radical chemistry had also explained the respirasome supercomplex associations in the mitochondrial system (Manoj et al., 2019a). Myoglobin, although a hemeprotein involved in oxygen-binding, is a monomer, because it has little roles in oxidative phosphorylation of ADP. From another perspective, $\mathrm{Mb}$ also shows sigmoid oxygen binding curves (Nerimetla et al., 2017), although they have been interpreted as hyperbolic. This signifies that the profiles obtained in $\mathrm{Hb}$ are due to the involvement of DROS equilibriums (FeIII-superoxide is also involved, not just FeIIoxygen!). The fact that $\mathrm{Hb}-\beta$ monomer has two channels (Figure 7) for oxygen/superoxide access/exit to/from hemeFe (which is conserved even in the sickle and thalassemic forms) supports the murburn perspective. We have not seen this aspect of $\mathrm{Hb}-\beta$ being attributed any physiological functions in our survey of literature. We project that the larger active site pocket volumes of the beta monomer in sickle cell and thalassemic states (in comparison to the normal beta monomer) could lead to deleterious DROS dynamics in physiology.

4. Non-specific glycations and phosphorylations of various biological components are observed in RBCs, and many such outcomes have relevance in several signaling pathways and some present pathophysiological manifestations (Grancara et al., 2015; Nedić et al., 2013; Zhang et al., 2009). Some of these can be explained with the relevance of DROS-based murburn reaction chemistry. (Seen in another way- if proteins can get glycated and phosphorylated by DROS, why can't ADP get phosphorylated?)

5. It is a significant consideration that from the time of Hb-oxygenation in lungs, RBCs take at least a few seconds to reach the various parts of the body (as blood moves at $\sim 3$ feet per second). Therefore, significant amount of dissociations occur within this time range. At high oxygen and reducing equivalents (NADH) concentrations, ample ATP is formed. Binding of this 
ATP/NADH to heme pocket of $\mathrm{Hb}$ (Figures $3 \& 4$ ) could serve as a lid preventing the escape of oxygen from the active site, thereby facilitating oxygen transport by $\mathrm{Hb}$.

6. The binding of organic and inorganic phosphates to globins' active site has been reported and characterized earlier (Yoshida \& Izuka, 1976). In the classical perspective, it is difficult to rationalize the cause-consequence sequence for the effect of 2,3-BPG on the structural dynamics of $\mathrm{Hb}$ tetramer. That is- the effector (2,3-BPG) can bind only within the large cavity of the tense form. However, the cavity will only be formed if the active site ligand (oxygen) is not present! It is unlikely that the small molecule of 2,3-BPG could push against the "inaccessible site" and liberate oxygen and make the $\mathrm{Hb}$ monomers tense, so as to get itself a binding slot on the tetramer. The murburn perspective of binding of 2,3-BPG at the active site is a parsimonious and direct explanation for some of the effects posed by the same ligand. It is known that 2,3-BPG binding is associated with the deoxygenated state of $\mathrm{Hb}$, and this is visually justifiable from the active site visualization shown in Figure 5. The data for 2,3-BPG binding at active site is also in the order $\mathrm{HbB}>\mathrm{HbA}>\mathrm{HbF}$, which justifies the fetal physiological requirements (for receiving oxygen from mother's blood supply). Further, the allosteric 2,3-BPG is always picked up by the docking procedure in the beta-monomers (and the process clearly demarcates between other small molecules like 1,3-BPH and 3-phosphoglycerate), signifying the efficiency of the protocol. The combined effects of poor ADP binding, high ATP/NADH binding, low 2,3-BPG binding at the heme-pocket and the energetically favorable 2,3-BPG binding at the allosteric site would render the energy metabolism and oxygen transfer by $\mathrm{HbS}$ and $\mathrm{HbE}$ inefficient. Such functionality-based argument is more appropriate than a merely structure-based $\mathrm{Hb}$ stacking failure in sickle-cell RBCs. (That is- all Hbs in sickle cell individuals have the same structural fault. Then, why do only some of the RBCs of such individuals sickle? In contrast, the murburn perspective mandates that depending on the circumstances, the metabolic activities of some cells could get skewed because of inefficient catalysis, thereby denying the cell the necessary energy requirements, leading to sickling.) Among a host of factors like temperature surrounding RBCs, $\mathrm{pH}, \mathrm{CO}_{2}$ concentration and $\mathrm{pO}_{2}$, one of the key determinants of $\mathrm{RBCs}$ ' shape is the concentration of ATP and 2,3-BPG. ATP concentrations maintain the discocyte shape of RBCs, while depletion of ATP has been shown to lead to formation of echinocytic shaped cells. This is because ATP minimizes the cytoskeletal stiffness and hence, lower ATP concentrations cause 
contraction of the cytoskeleton, causing the formation of spicules on RBC surface by pulling the bilayer over a smaller projected area and increased $\mathrm{O}_{2}$ requirement because of the higher volume: area ratio caused by the shape change. ATP as well as other organic phosphates have higher affinity for deoxyHb, and therefore, maintain RBC in deoxygenated state (Benesch and Benesch, 1967; Chowdhury et al., 2017). In many diseases, the varying shape (poikilocytosis) and morphology (anisocytosis) of the RBCs is a key factor - for example, in thalassemia and splenomegaly, the shape of the RBCs is teardrop shaped (dacrocytes) and in other cases, we have other variations. The biconcave disc shape is ideal for rapid gaseous exchange. ATP and other organic phosphates influence RBC shapes. The shape of the oxygen dissociation curve depends on allosteric modulators such as 2,3-BPG (and ATP/ADP?). Lower $\mathrm{O}_{2}$ concentrations (such as in metabolic acidosis) trigger release of ATP and this would induce shape changes in RBCs (Sridharan et al., 2010). Glycolysis can occur in the absence of oxygen; however, to achieve very high (mM) concentrations of ATP, the RBCs would need normoxic $\mathrm{O}_{2}$ concentrations. Each RBC has an estimated 260 million Hb molecules. Any decrease in iron levels (anemia) would mean lesser Fe/heme is available for DROS formation and thereby, lack of ATP would directly affect RBCs' shape and tissue oxygenation, because gaseous exchange is directly correlated to shape of the RBCs. ATP has been proposed to be an extracellular molecule (due to its role in cAMP formation and signaling) which is released by healthy RBCs in response to hypoxia to trigger vasodilation (as a protective measure) and by oxidatively stressed / malaria infected RBCs (Ramdani and Langsley, 2014). These are some of the implications that could be reinvestigated with the insight provided by murburn perspective.

\section{Conclusions}

The DROS-based ATP-synthesis and redox cycle stochastic mechanism not only accounts for the $\mathrm{mM}$ level of ATP observed in RBCs but also presents a thermodynamically and probabilistically viable proposal. Our hypothesis opens doors to explore further avenues, on the far reaching physiological and pathological implications of modulating reactive oxygen species as a key

player (not always the villain) while designing personalized treatment regimes for type 2 diabetes, sickle cell anemia, thalassemia and microvascular dysfunction. Summing up, the new murburn perspective for $\mathrm{Hb}$ function affords a "win-win" situation for $\mathrm{RBC}$ wherein $\mathrm{Hb}$ could 
simultaneously serve as an oxygen transportation, ATP generation and NADH recycle modality. Although protons are in plenty within RBCs (enabling facile DROS dismutations and thereby lowering yields), this is offset by the high packing density of $\mathrm{Hb}$. Since erythrocytes lack the mitochondrial Complex $\mathrm{V}$ or $F_{o} F_{1} \mathrm{ATP}($ synth)ase, the millimolar amounts of ATP formed in $\mathrm{RBC}$ is direct evidence of the murburn model functioning of $\mathrm{Hb}$.

Declarations: The authors have no conflict of interests to declare. The work was powered by Satyamjayatu: The Science \& Ethics Foundation. KMM thanks Prof. N. M. Bazhin (Russian Academy of Sciences) for discussions.

\section{References}

Balagopalakrishna, C., Manoharan, P.T., Abugo, O.O., and Rifkind, J.M. (1996). Production of superoxide from hemoglobin-bound oxygen under hypoxic conditions. Biochemistry 35, 63936398.

Banerjee, M., Chakrabarti, A., and Basu, S. (2012). Oxidative interaction between oxyHb and ATP: a spectroscopic study. The Journal of Physical Chemistry B 116, 6150-6157.

Benesch, R., and Benesch, R.E. (1967). The effect of organic phosphates from the human erythrocyte on the allosteric properties of hemoglobin. Biochemical and Biophysical Research Communications 26, 162-167.

Berg, J.M., Tymoczko, J.L., and Stryer, L. (2002). Biochemistry (New York: WH Freeman).

Bryk, A.H., and Wiśniewski, J.R. (2017). Quantitative analysis of human red blood cell proteome. Journal of Proteome Research 16, 2752-2761.

Cashon, R., Bonaventura, C., Bonaventura, J., and Focesi, A. (1986). The nicotinamide adenine dinucleotides as allosteric effectors of human hemoglobin. Journal of Biological Chemistry 261, 12700-12705.

Chowdhury, A., Dasgupta, R., and Majumder, S.K. (2017). Changes in hemoglobin-oxygen affinity with shape variations of red blood cells. Journal of Biomedical Optics 22, 105006.

Cox, M.M., and Nelson, D.L. (2008). Lehninger Principles of Biochemistry (WH Freeman).

DeLano, W.L. (2002). Pymol: An open-source molecular graphics tool. CCP4 Newsletter on Protein Crystallography 40, 82-92. 
Ellsworth, M.L., and Sprague, R.S. (2012). Regulation of blood flow distribution in skeletal muscle: role of erythrocyte-released ATP. The Journal of Physiology 590, 4985-4991.

Ellsworth, M.L., Ellis, C.G., and Sprague, R.S. (2016). Role of erythrocyte-released ATP in the regulation of microvascular oxygen supply in skeletal muscle. Acta Physiologica 216, 265-276.

Ellsworth, M.L., Graham, M.R., and Achilleus, D. (2006). Reactive oxygen species and erythrocyte-released ATP: Is there a connection. The FASEB Journal 20, A273-A273 (Wiley Online Library).

Forli, W., Halliday, S., Belew, R., and Olson, A.J. (2012). AutoDock Version 4.2. Journal of Medicinal Chemistry 55, 623-638.

Garrett, R.H., and Grisham, C.M. (1999). Biochemistry (Saunders College Publishing Fort Worth).

Gideon, D.A., Nirusimhan, V., and Manoj, K.M. (2020). Are plastocyanin and ferredoxin specific electron carriers or generic redox capacitors? Classical and murburn perspectives on two photosynthetic proteins. Journal of Biomolecular Structure and Dynamics (Oct 2020), 1-15.

Giulivi, C., Hochstein, P., and Davies, K.J. (1994). Hydrogen peroxide production by red blood cells. Free Radical Biology and Medicine 16, 123-129.

González-Alonso, J., Olsen, D.B., and Saltin, B. (2002). Erythrocyte and the regulation of human skeletal muscle blood flow and oxygen delivery: role of circulating ATP. Circulation Research 91, 1046-1055.

Grancara, S., Zonta, F., Ohkubo, S., Brunati, A.M., Agostinelli, E., and Toninello, A. (2015). Pathophysiological implications of mitochondrial oxidative stress mediated by mitochondriotropic agents and polyamines: the role of tyrosine phosphorylation. Amino Acids 47, 869-883.

Gupta, R.K., Benovic, J.L., and Rose, Z.B. (1978). Magnetic resonance studies of the binding of ATP and cations to human hemoglobin. The Journal of Biological Chemistry 253, 6165-6171.

Harlow, G.R., and Halpert, J.R. (1998). Analysis of human cytochrome P450 3A4 cooperativity: construction and characterization of a site-directed mutant that displays hyperbolic steroid hydroxylation kinetics. Proceedings of the National Academy of Sciences 95, 6636-6641.

Inohara, K., Kimura, I. \& Yuan, C. (2013). Suppressive effect of ATP on autoxidation of tuna oxymyoglobin to metmyoglobin. Fisheries Science 79, 503-511.

Jacob, V.D., and Manoj, K.M. (2019). Are adipocytes and ROS villains, or are they protagonists in the drama of life? The murburn perspective. Adipobiology 10, 7-16. 
Jensen, K.P., and Ryde, U. (2004). How $\mathrm{O}_{2}$ binds to heme: Reasons for rapid binding and spin inversion. Journal of Biological Chemistry 279, 14561-14569.

Lo, H.H., and Schimmel, P.R. (1969). Interaction of human hemoglobin with adenine nucleotides. The Journal of Biological Chemistry 244, 5084-5086.

Lu, S.-J., Feng, Q., Park, J.S., Vida, L., Lee, B.-S., Strausbauch, M., Wettstein, P.J., Honig, G.R., and Lanza, R. (2008). Biologic properties and enucleation of red blood cells from human embryonic stem cells. Blood, The Journal of the American Society of Hematology 112, 44754484.

Manoj, K.M., and Manekkathodi, A. (2021). Light's interaction with pigments in chloroplasts: The murburn perspective. Journal of Photochemistry and Photobiology 5, 100015.

Manoj, K.M., et al. (2019a). Aerobic respiration: proof of concept for the oxygen-centric murburn perspective. Journal of Biomolecular Structure and Dynamics 37, 4542-4556.

Manoj, K.M., Parashar, A., Gade, S.K., and Venkatachalam, A. (2016a). Functioning of microsomal cytochrome P450s: Murburn concept explains the metabolism of xenobiotics in hepatocytes. Frontiers in pharmacology 7, 161.

Manoj, K.M., et al. (2016b). Atypical profiles and modulations of heme-enzymes catalyzed outcomes by low amounts of diverse additives suggest diffusible radicals' obligatory involvement in such redox reactions. Biochimie 125, 91-111.

Manoj K.M., et al. (2016c). Electron transfer amongst flavo- and hemo-proteins: diffusible species effect the relay processes, not protein-protein binding. RSC Advances 6, 24121-24129.

Manoj, K.M., Ramasamy, S., Parashar, A., Gideon, D.A., Soman, V., Jacob, V.D., and Pakshirajan, K. (2020). Acute toxicity of cyanide in aerobic respiration: Theoretical and experimental support for murburn explanation. Biomolecular concepts 11, 32-56.

Manoj, K.M., et al. (2019b). Chemiosmotic and murburn explanations for aerobic respiration: predictive capabilities, structure-function correlations and chemico-physical logic. Archives of Biochemistry and Biophysics 676, 108128.

Mazzarella, L., Merlino, A., Balasco, N., Balsamo, A., and Vergara, A. (2018). Crystal structure of the ferric homotetrameric $\beta 4$ human hemoglobin. Biophysical Chemistry 240, 9-14.

Nedić, O., Rattan, S., Grune, T., and Trougakos, I. (2013). Molecular effects of advanced glycation end products on cell signalling pathways, ageing and pathophysiology. Free Radical Research 47, 28-38.

Nerimetla, R., et al. (2017). Species-specificity in myoglobin oxygenation and reduction potential properties. Meat and Muscle Biology 1, 1-7. 
Novak, Z., Kovacs, J., Waart, F.V., Fisher, T., Johnson, C., and Meiselman, H. (1998). Superoxide production and deformability of erythrocytes in sickle cell disease 789. Pediatric Research 43, 137-137.

Ogo, S., Focesi, A. Jr., Cashon, R., Bonaventura, J., and Bonaventura, C. (1989). Interactions of nicotinamide adenine dinucleotides with varied states and forms of hemoglobin. Journal of Biological Chemistry 264, 11302-11306.

Pandey, K.B., and Rizvi, S.I. (2011). Biomarkers of oxidative stress in red blood cells. Biomedical Papers of the Medical Faculty of Palacky University in Olomouc 155(2).

Parashar, A., and Manoj, K.M. (2021). Murburn precepts for cytochrome P450 mediated drug/xenobiotic metabolism and homeostasis. Current Drug Metabolism. PMID: 33461459

Peng, W., Liu, X., Zhang, W., and Li, G. (2003). An electrochemical investigation of effect of ATP on hemoglobin. Biophysical Chemistry 106, 267-273.

Pettersen, E.F., Goddard, T.D., Huang, C.C., Couch, G.S., Greenblatt, D.M., Meng, E.C., and Ferrin, T.E. (2004). UCSF Chimera-a visualization system for exploratory research and analysis. Journal of Computational Chemistry 25, 1605-1612.

Ramdani, G., and Langsley, G. (2014). ATP, an extracellular signaling molecule in red blood cells: a messenger for malaria? Biomedical Journal 37, 284-92.

Scarpa, M., Rigo, A., Orsega, E.F., and Viglino, P. (2011). Generation of the Superoxide radical in the red blood cell. Paper presented at: Oxygen Radicals in Chemistry and Biology: Proceedings, 3 International Conference, Neuherberg, Federal Republic of Germany, July 10-15, 1983 (Walter de Gruyter).

Schacter, L. (1986). Generation of superoxide anion and hydrogen peroxide by erythrocytes from individuals with sickle trait or normal haemoglobin. European Journal of Clinical Investigation $16,204-210$.

Sen, U., Dasgupta, J., Choudhury, D., Datta, P., Chakrabarti, A., Chakrabarty, S.B., Chakrabarty, A., and Dattagupta, J.K. (2004). Crystal structures of $\mathrm{HbA} 2$ and $\mathrm{HbE}$ and modeling of hemoglobin 84 : interpretation of the thermal stability and the antisickling effect of $\mathrm{HbA} 2$ and identification of the ferrocyanide binding site in Hb. Biochemistry 43, 12477-12488.

Song, J., Yoon, D., Christensen, R.D., Horvathova, M., Thiagarajan, P., and Prchal, J.T. (2015). HIF-mediated increased ROS from reduced mitophagy and decreased catalase causes neocytolysis. Journal of Molecular Medicine 93, 857-866.

Sprague, R.S., Goldman, D., Bowles, E.A., Achilleus, D., Stephenson, A.H., Ellis, C.G., and Ellsworth, M.L. (2010). Divergent effects of low- $\mathrm{O}_{2}$ tension and iloprost on ATP release from 
erythrocytes of humans with type 2 diabetes: implications for $\mathrm{O}_{2}$ supply to skeletal muscle. American Journal of Physiology-Heart and Circulatory Physiology 299, H566-H573.

Sprague, R.S., Hanson, M.S., Achilleus, D., Bowles, E.A., Stephenson, A.H., Sridharan, M., Adderley, S., Procknow, J., and Ellsworth, M.L. (2009). Rabbit erythrocytes release ATP and dilate skeletal muscle arterioles in the presence of reduced oxygen tension. Pharmacological Reports 61, 183-190.

Sridharan, M., Adderley, S.P., Bowles, E.A., Egan, T.M., Stephenson, A.H., Ellsworth, M.L., and Sprague, R.S. (2010). Pannexin 1 is the conduit for low oxygen tension-induced ATP release from human erythrocytes. American Journal of Physiology-Heart and Circulatory Physiology 299, H1146-H1152.

Strader, M.B., Hicks, W.A., Kassa, T., Singleton, E., Soman, J., Olson, J.S., Weiss, M.J., Mollan, T.L., Wilson, M.T., and Alayash, A.I. (2014). Post-translational transformation of methionine to aspartate is catalyzed by heme iron and driven by peroxide: a novel subunit-specific mechanism in hemoglobin. Journal of Biological Chemistry 289, 22342-22357.

Turpin, C., Catan, A., Guerin-Dubourg, A., Debussche, X., Bravo, S.B., Álvarez, E., Van Den Elsen, J., Meilhac, O., Rondeau, P., and Bourdon, E. (2020). Enhanced oxidative stress and damage in glycated erythrocytes. PloS One 15, e0235335.

Venkatachalam, A., Parashar, A., and Manoj, K.M. (2016b). Functioning of drug-metabolizing microsomal cytochrome P450s: In silico probing of proteins suggests that the distal heme 'active site' pocket plays a relatively 'passive role' in some enzyme-substrate interactions. In Silico Pharmacology 4(1), 2.

Wilbur, S., Williams, M., Williams, R., Scinicariello, F., Klotzbach, J., Diamond, G., and Citra, M. (2012). Toxicological profile for carbon monoxide. Agency for Toxic Substances and Disease Registry (US); Table 3-12.

Winterbourn, C.C. (1990). Oxidative reactions of hemoglobin. Methods in Enzymology 186, 265-272.

Yoshida, S., Iizuka, T. (1976). Effects of organic and inorganic phosphate ions on the chargetransfer band of ferric myoglobin. Biochimica et Biophysica Acta. 434, 505-508.

Yu, J., Zhou, Y., Tanaka, I., and Yao, M. (2010). Roll: a new algorithm for the detection of protein pockets and cavities with a rolling probe sphere. Bioinformatics 26, 46-52.

Yubisui, T., Takeshita, M., and Yoneyama, Y. (1980). Reduction of methemoglobin through flavin at the physiological concentration by NADPH-flavin reductase of human erythrocytes. The Journal of Biochemistry 87, 1715-1720. 
Zhang, Q., Ames, J.M., Smith, R.D., Baynes, J.W., and Metz, T.O. (2009). A perspective on the Maillard reaction and the analysis of protein glycation by mass spectrometry: probing the pathogenesis of chronic disease. Journal of Proteome Research 8, 754-769. 